\title{
Takotsubo cardiomyopathy during elective general anaesthetic induction
}

\author{
Manoj Goonewardene, Shahid Aziz
}

Department of Cardiology, Southmead General Hospital, Bristol, UK

Correspondence to Dr Manoj Goonewardene, moj@doctors.org.uk

\section{DESCRIPTION}

This 55-year-old lady became acutely hypotensive during induction of anaesthesia with fentanyl, propofol and atracurium for elective cholecystectomy. She developed anterior ST segment elevation and runs of ventricular tachycardia. The operation was abandoned, and subsequent ECGs showed a deep T-wave inversion in the anterolateral leads (figure 1). Her troponin was elevated.

The patient underwent cardiac catheterisation which showed normal coronary arteries. Left ventricular angiography showed systolic ballooning of the apex with hyper dynamic contraction of the base (figure 2). The appearances were characteristic of Takotsubo cardiomyopathy. The patient subsequently made a full recovery and left ventricular function returned to normal within days.

Takotsubo cardiomyopathy is a rare condition and is also known as transient left ventricular apical ballooning syndrome, stress cardiomyopathy or broken heart syndrome. It has typically been associated with acute chest pain in postmenopausal women following a stressful life event. Over the last few years, there have been case reports of Takosubo cardiomyopathy associated with exacerbations of psychiatric illness, ${ }^{1}$ pheochromocytoma, ${ }^{2}$ acute subarachnoid haemorrhage, ${ }^{3}$ sepsis, drugs and anaesthesia. It now seems more common than previously thought with multiple precipitating factors. Excessive

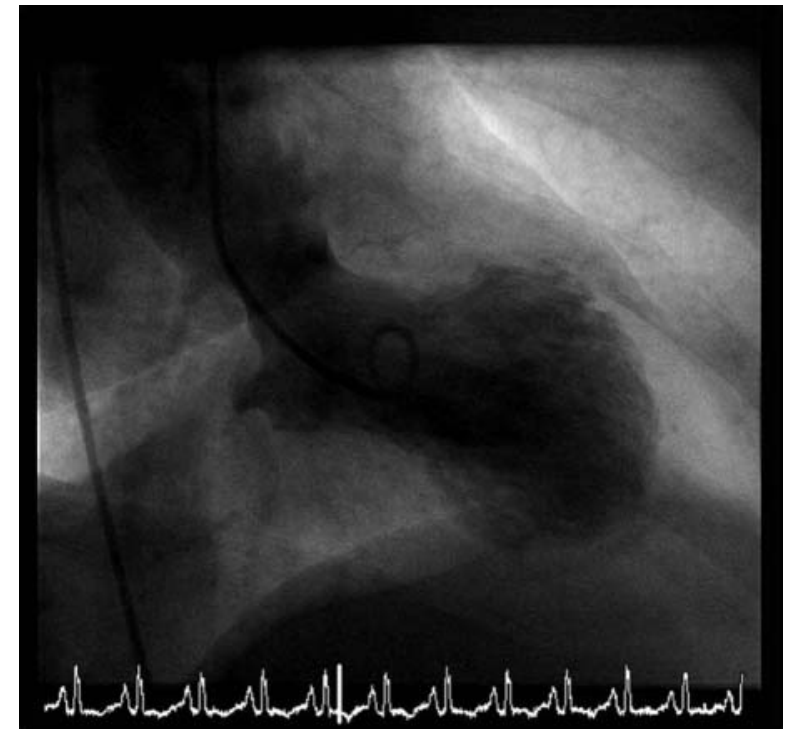

Figure 2 Left ventricular systolic angiogram frame shows apical ballooning and basal contraction.

catecholamine secretion has been suggested as the likely mechanism for myocardial dysfunction. This case illustrates an unusual presentation with dramatic

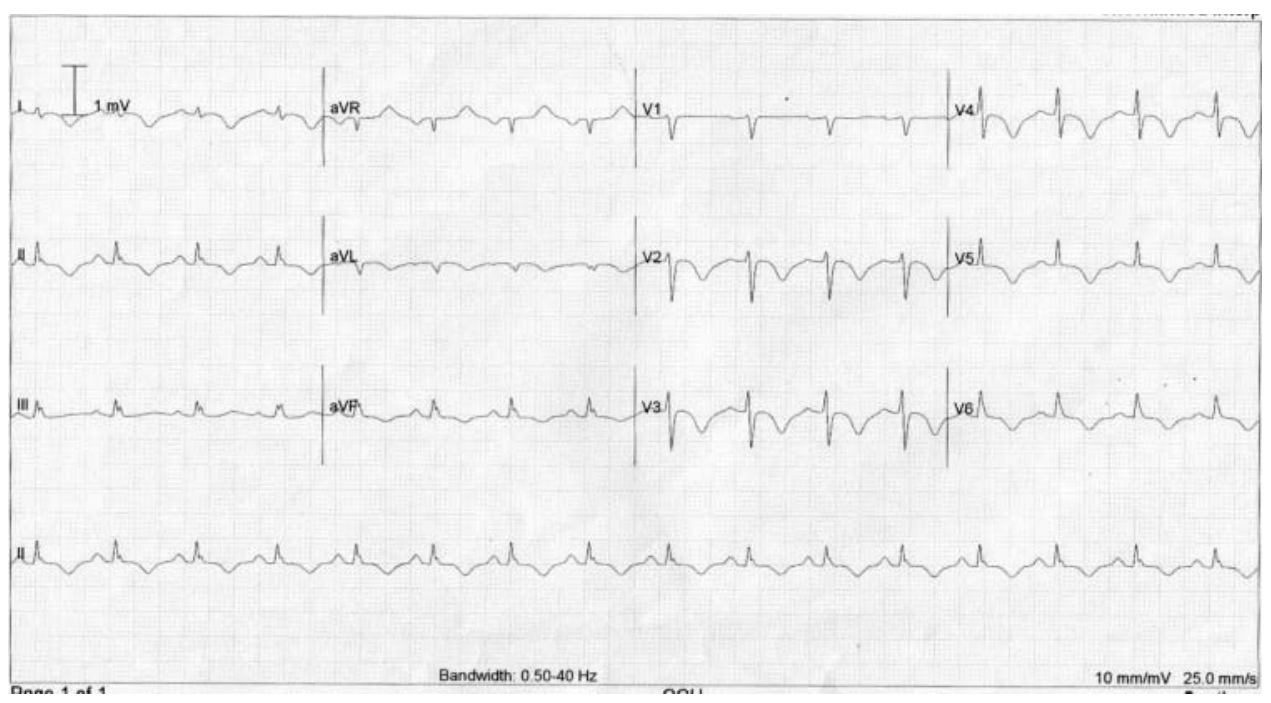

Figure 1 ECG immediately after postanaesthetic induction. 


\section{BMJ Case Reports}

haemodynamic and ECG changes at the time of anaesthetic induction, and will hopefully increase awareness of this condition.

\section{Learning points}

- Takotsubo is a rare transient cardiomyopathy associated with chest pain, acute ST elevation and troponin release.

- The key finding is transient apical left ventricular systolic dysfunction (apical ballooning) seen on imaging (echo, angiography and cardiac MR) associated with no significant epicardial coronary stenosis.

- Multiple causes including acute stress, anaesthetic induction, sepsis, pheochromocytoma, drugs, acute subarachnoid haemorrhage and acute psychiatric illness. The underlying mechanism is thought to be acute excessive catecholamine release.

\section{Competing interests None.}

Patient consent Obtained.

\section{REFERENCES}

1. Corrigan F, Kimmel M, Jayaram G. Four cases of Takotsubo cardiomyopathy linked with exacerbations of psychiatric illness. Innov Clin Neurosci 2011;8:50-3.

2. Park J, Kim K, Sul J, et al. Prevalence and patterns of left ventricular dysfunction in patients with pheochromocytoma. J Cardiovasc Ultrasound 2011;19:76-82.

3. Franco C, Khaled B, Afonso L, et al. Acute subarachnoid hemorrhage and cardiac abnormalities: Takotsubo cardiomyopathy or neurogenic stunned myocardium? A case report. Cases J 2010;3:81.

This pdf has been created automatically from the final edited text and images.

Copyright 2012 BMJ Publishing Group. All rights reserved. For permission to reuse any of this content visit http://group.bmj.com/group/rights-licensing/permissions.

BMJ Case Report Fellows may re-use this article for personal use and teaching without any further permission.

Please cite this article as follows (you will need to access the article online to obtain the date of publication).

Goonewardene M, Aziz S. Takotsubo cardiomyopathy during elective general anaesthetic induction. BMJ Case Reports 2012;10.1136/bcr-2012-006373, Published XXX

Become a Fellow of BMJ Case Reports today and you can:

- Submit as many cases as you like

- Enjoy fast sympathetic peer review and rapid publication of accepted articles

- Access all the published articles

- Re-use any of the published material for personal use and teaching without further permission

For information on Institutional Fellowships contact consortiasales@bmjgroup.com

Visit casereports.bmj.com for more articles like this and to become a Fellow 